<紹 介 >

赤外線放射温度計 PRT-4 について

田中邦一”。丸岡大鿆"

\title{
Introduction of Infrared Radiation Thermometer Model PRT-4
}

K. Tanaka, D. Maruoka

\section{1. まえがき}

最近の技術の進少にはめざましいものがある。この 中には，光あるいは電波などいわゆる電磁波のさまざ まな波長域に対する開発利用がある。これは種々な電 磁波波長域の検出装置の開発と小型化の結果に潘かな らない。特に,この小型化の成功は航空機あるいは人 工衛星への塔載を可能にし, 空中式 (Ari bone) に よる遠隔探査 ${ }^{1)}$ を促進させる事となった。日本に打け る遠隔探査については可視域の波長と近赤外域の波長 の一部走利用するいわゆる空中写真方式が为っとも広 く用いられているが，その他の波長を利用した遠隔探 査については通商産業省地質調査所の松野博士等 2 2) 3) による赤外線映像装置の開発と地温探査への応用のほ か, 気象庁子報課の土屋清博士による赤外線放射温度 計を利用した地表温度の测定，あるいは海上保安广开の 例等まだ数例を見るにすぎず，ようやく開発利用の緒
についた段階といえよう。

しかるに, 純粋な学術的調査のみならず, 地域開発 海洋開発などに伴う各種土木工事の基礎調査も大型化 し, かつ調査にも重点が置かれ, しかもこれらの調査 期間は短く，精度は高く，結果は総観的なものが要求 されてきている。このような社会的必要性を満足させ るには，量的情報と質的情報を同時に提供する空中写 真がこの上ない电のとしてあらゆる分野で利用されて きたが，新らたに温度の情報を得る手段として，アジ ア航測 K.K Kでは, 空中写真同様空中方式により連続的 に地表面温度が測定できる赤外線放射温度計 PRT-4 (アメリカバーネス社製)を設備し，空中写真と結びつ ける事によって遠隔探査の幅を広げる努力を行なって きた。その結果は, 種々な分野で応用できるものと思 われる。

本稿では, 種々な分野での利用に先立ち, 赤外線放 射温度計 PRT-4 と本機を使って試みた 2 ～ 3 の実例

Photo 1

光学ヘッド

Photo 2 本体

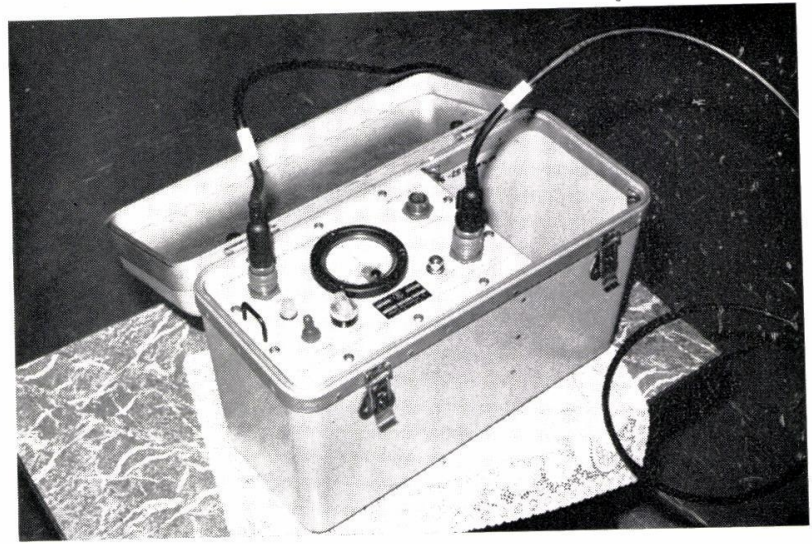

* アジア航测生産事業部地質課

「写真測量」Vol. 7 No. 21968

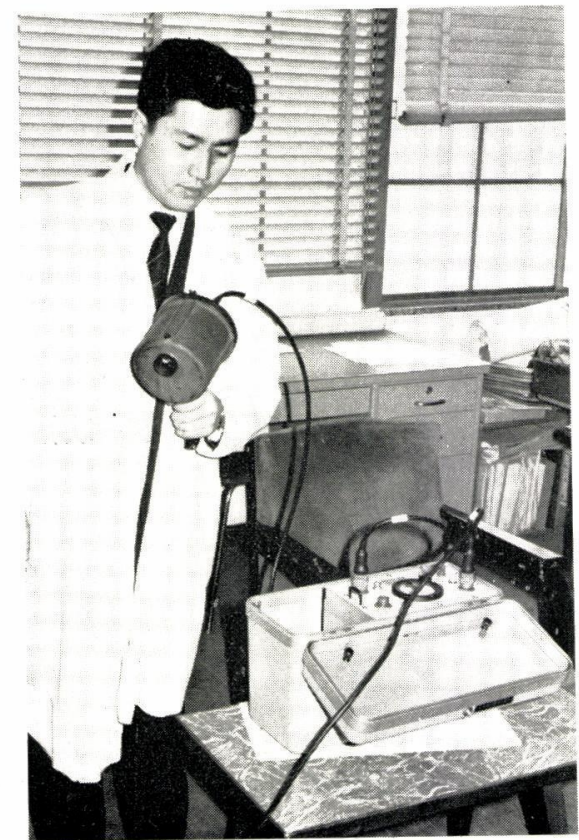


について紹介してみたい。

\section{2. 赤外線による温度測定の原理}

通常, 絶対温度が零度 $\left(-273.16^{\circ} \mathrm{C}\right)$ 以上にあるあ らゆる物体は，その温度に比例して原子や分子の固有 振動を行なっている。同時にこの固有振動によって発 生される電磁波を放射している。この放射強度と波長 の関係を示したものが Fig. 1 である。これによれば， 最大放射を示す波長は，温度が低くなるに従い長波長 側に移行しており，すなわち太陽光 $\left(6000^{\circ} \mathrm{K}\right)$ ではお よそ $5 \mu$ のところにあるが, 常温附近の物体 $\left(\right.$ 約 $300^{\circ} \mathrm{K}$ ) では $9 \sim 10 \mu$ のところにある。

さて赤外線とは，可視光線のプリズム分光によって みられる赤色端以上の長波長，打上そ $0.7 \mu \sim 1500 \mu$ 位までの波長域の電磁波の総称であるが，この赤外線

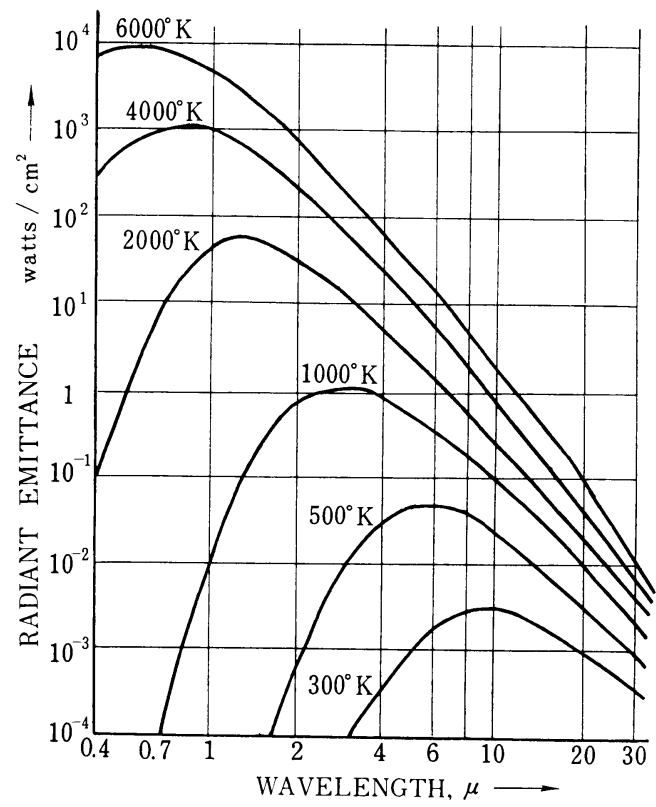

Fig. 1 電磁波の放射強度と波長の関係
領域のうち $9 \sim 10 \mu$ 前後の波長を用い, 物体からの赤 外線放射を検出すれば，その強度差から物体の表面温 度を物体に触れる事なしに測定できるわけである。こ れが赤外線による温度測定の原理である。

この赤外線検出には大別して, 熱検出器と光検出器 に分類される。このうち熱検出器とは, 赤外線の熱効 果゙に主眼をおいてこれを受け，受信部の温度上昇を電 気信号に変えて検出する装置を有するもので, 熱電対 サーミスターボロメーターがこれに属し, 分光器用の 検出器として古くから実用化されている。一方, 光検 出器とは, 入射赤外線が受光部の電子系に吸収され, 電子が他のレベルへ移動する際生じる受光部の電気的 性質の変化を利用するものである。特に最近では, 光 伝導セル Photovoltaic 検出器, Photoelectromagentic 検出器等入射赤外線の変化に追随しうる速度がマイク 口秒級の高感度の検出装置が開発されている。

熱検出器は波長特性が一様であるが, 光検出器は比 較的短波長の赤外放射線に対しては高い検出能力を持 つが，長波長に対して感度は落ちるといわれている。

\section{3. 赤外線放射温度計 PRT-4 の機構}

本機はアメリカ, バーネス社製の赤外線放射温度計 であり，特に携带用に供せられるようバッテリ一出力 によって作動できるよう，また全体的にコンパクトに 設計されている。本機の形体は写真 1 と 2 に示される ように，本体のエレクトロニクスユニット（電子回路 部）と光学ヘッド（感温部）からなっている。Fig. 2 は本機の構造を詳しく示したものである。これを用い ての測温は, 先ず光学ヘッドを被測温物体に向け，物

* 物体の温度に比例して放射される電磁波のエネ ルギーは，他の物体にあたると一部は反射し， 一部は透過するが，ある波長部分は吸収されて 発熱する。特に, この効果が赤外線波長域では 強くめらわれる。このため赤外線はしばしば熱 放射線と呼ばれている。

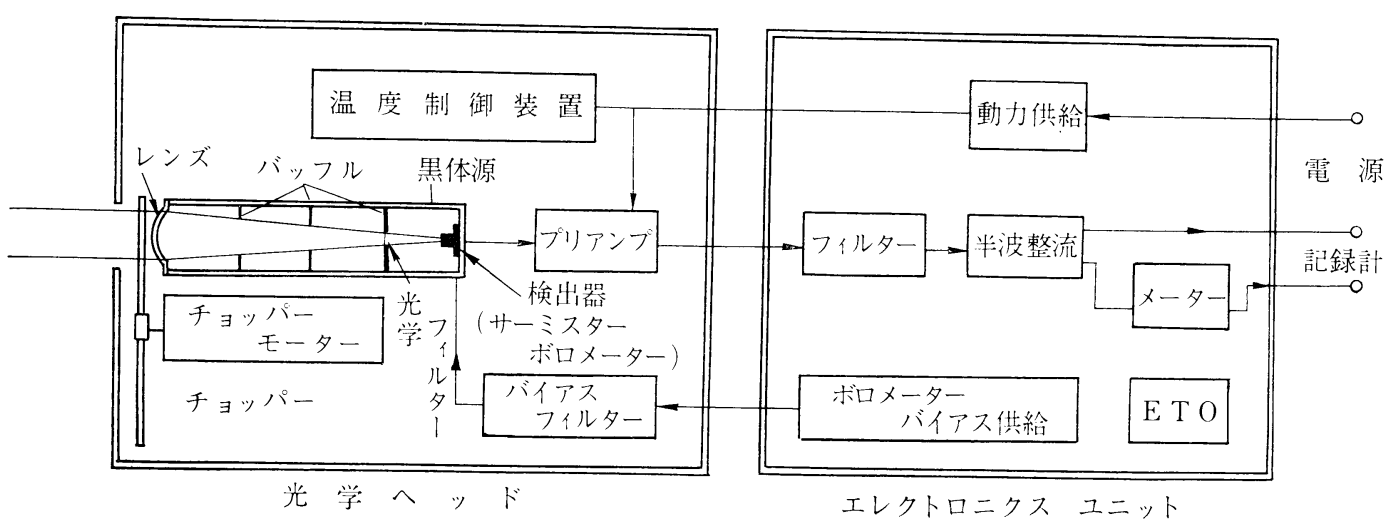

Fig. 2 放射温度計の構造 (バーンズ社製 Model PRT-4) 


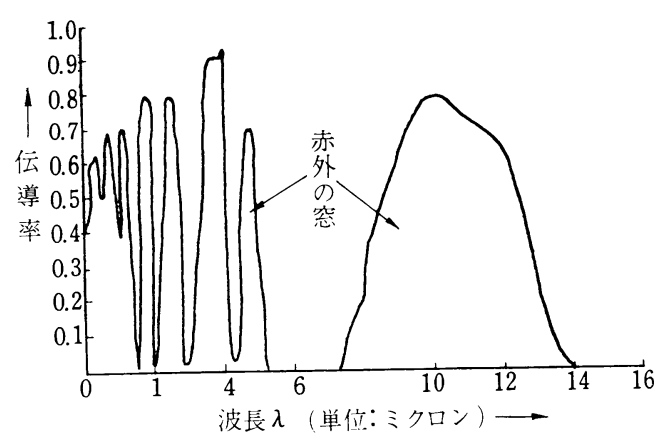

Fig. 3 大気中の選択吸収の様子

体からの放射エネルギーを検出する。検出素子はサー ミスターボロメーターを用いた熱検出器で黒体錐状洞 の底部についている。入射孔より入った赤外線はあら かじめ一定 $\left(55^{\circ} \mathrm{C}\right)$ に保たれた黑体錐状洞から放射さ れる赤外線と入光部チョッパーによって対比され電気 信号に変えられる。この電気信号はさらに光学へッド 内部にあるプリアンプで増幅され，本体の電子回路部 に送られる。電子回路部では，この信号を増幅して指 示部のメーターに華氏 $\left({ }^{\circ} \mathrm{F}\right)$ で示されるようになって いる。と同時にその信号を取り出してオシログラフ等 に記録することもできる機構を有している。

本機が利用している赤外線波長域は 8 14 $\mu$ で, 湘 定可能な温度範囲は $-12^{\circ} \mathrm{C} \sim+44^{\circ} \mathrm{C}$ である。スペク トルバンドが 8〜14 $\mu$ に限定されているのは, 赤外線 の大気中の選抧吸収をさ壮空中からの遠隔探查ができ るようにしてあるからである。Fig. 3 は大気中を伝わ るスペクトルの選択吸収の様子を示すものであるが,

図から分るように $14 \mu$ 以上では非常に大きい吸収を 示す。吸収帯と吸収帯の間の波長領域は“大気の空” (Atomspheric window) と呼ばれ実際の測定対象とな る部分であり,本機が用いているのもこの“大気の空” の波長域に他ならない。この波長域の選択はフィルタ 一によってなされ，短かい波長の除去はアンチモナイ ドインヂウムにより, 長い、波長の除去はイラトランに よってなされている。

以上が大体本機の機構であるが，本機の主な性能を まとめると次の通りである。

\begin{tabular}{|c|c|}
\hline 温度測定範国 & $-12^{\circ} \mathrm{C} \sim+44^{\circ} \mathrm{C}$ \\
\hline 精度 & $0.2^{\circ} \mathrm{C}$ \\
\hline 測 定 距 離 & $30 \mathrm{~cm}$ 無限長 \\
\hline 応 答 測 度 & $50 \mathrm{~ms}$ \\
\hline 穓测視野角 & $2^{\circ}$ \\
\hline 重量 $\left\{\begin{array}{l}\text { 光学ヘッド } \\
\text { 体 }\end{array}\right.$ & $\begin{array}{r}3^{1} /{ }_{2} \text { pond } \\
13^{1} / 4 \text { pond }\end{array}$ \\
\hline 定格電圧その他 & $115 \mathrm{~V} \mathrm{AC} \pm 10 \%$ \\
\hline & $50 \mathrm{c} / \mathrm{s}$ \\
\hline
\end{tabular}

消費電力 $20 \mathrm{~W}$

\section{4. 本 機 の 特 徵}

本機の構造については大体抢わかりいただけたと思 うが，この機械の特徴については充分理解し使用しな いと，その効果を半減させることにもなりか㸚ないの で，本機の特徴について箅条書にまとめて打く。

（1）赤外線の放射強度を検出することにより，あら ゆる物体の表面温度を物体に触れずに遠隔測定で きる。

（2）本機の検出する赤外線波長域は 8〜14 $\mu$ のいわ 的る“大気の空”の部分に限定されていることか ら, 大気中の水蒸気や炭酸ガスによる吸収を減少 させ雲, 海面, 地表面などの最高温度放射をとら えっることができる。

(3) 温度の测定は，スポットによるメータ一読定と 同時にオシログラフ等の自記記録により連続測 定もできる。

（4）测定精度は $0.2^{\circ} \mathrm{C}$ と高く，また応答速度が 50 ミリ秒と比較的早いこと,さらに小型で軽量であ ることの他 $(2)$, (3) の待徴と合せ空中探查に利用 できる。

(5)しかし，航空機に塔載しての調査は，航跡に沿 った温度分布であると同時に，観測視野角が $2^{\circ}$ で あることから Table 1 に示すように飛行高度に 比例した場所的な平均温度である。

(6) 空中からの調査では，単に記録紙からだけでは 測定位置の決定はできない。

Table 1 飛行高度と測定半径との関係

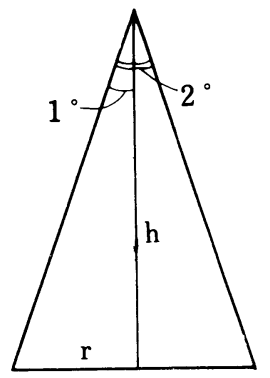

\begin{tabular}{|c|c|}
\hline 业行高度 & 測定半径 \\
\hline $750 \mathrm{~m}$ & $13.13 \mathrm{~m}$ \\
1500 & 26.25 \\
2250 & 39.38 \\
3000 & 52.50 \\
3750 & 65.63 \\
\hline
\end{tabular}

$r=h \times \tan 1^{\circ}$

\section{5. $2 \sim 3$ の実験についての報告}

本機の野外でのテストに先立ち，先ず前節で述べた (6)の点をカバーする事を考六，空中写真と同調させる よう計画し，若キの改良を加えた。先ず，測定点を求 めるために空中写真の撮影時の光軸と平行な赤外線入 射光が，得られるよう撮影機に孔をあけること。次に 温度の自記記録装置の撮影時と同調したマークをも同 時に記録できるよう改良を加えること，この二点がそ れであり,これらはアジア航測 $\mathrm{KK}$ 器材整備室の小山 


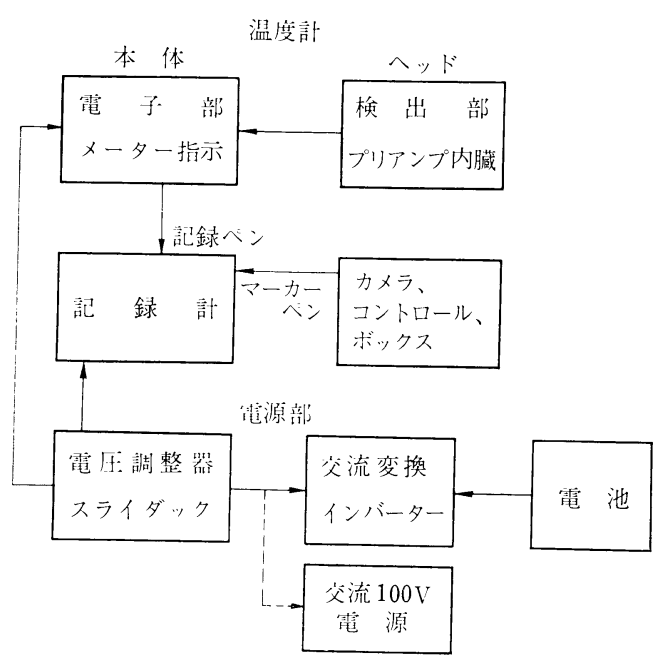

Fig. 4 測定のための系統図

氏と運航部の滝沢, 中村, 一ノ渡の各氏を中心に進め られた。この結果, 飛行機からの温度測定は Fig. 4 に示すような系統によって行なわれることとなった。 また実験を始めるに際して, 赤外線放射温度計は, 各温度に温めたウォーターバスの水面に向けて補正し た。

遠隔操作によって物体の温度を測る場合, 理想物体 である黒体**(black body) と一般物体である灰色体 (gray body) の全放射強度の比である放射率 (emissvity）が重要である。というのは，本来，赤外線放射 温度計の補正は，黒体の放射強度によってすべきであ る。しかしながら黒体の上うと放射率が 1.0 という物 体は理想物体であるから，放射率がこれに最为近い自 然物体を選んで補正しなければならない。現在分って いるものでは, 良く磨かれた銀板の放射率が 0.1 より さく,白金黒はもっとも黒体に近いということである。 その湾か自然物体である岩石や樹木などの放射率に関 しては基礎資料はそしく，詳しい事は分らないが，水 面はこれらのなかでもっとも黒体に近い散乱面を持っ た自然物であるといわれており，Brunt，Geiger， Brooks 等によると 7〜15 $\mu$ の幅の中で水面の放射率 は約 0.98 であると報告されている。そこで，本機の 補正には, ウォーターバスで温めた水面に光学ヘッド を向けて行ったわけである。

\section{A. 大島におけるテスト}

最初の実験は1966年 8 月14日に, 伊豆七島の一つで ある大島で行なった。温度の測定と撮影は Fig. 5 に 示すようなコースで, 13時20分〜30分の間に行なわれ

**黑体とは，入射した放射線のすべてを完全に吸 収し、また放射する物体をいう。

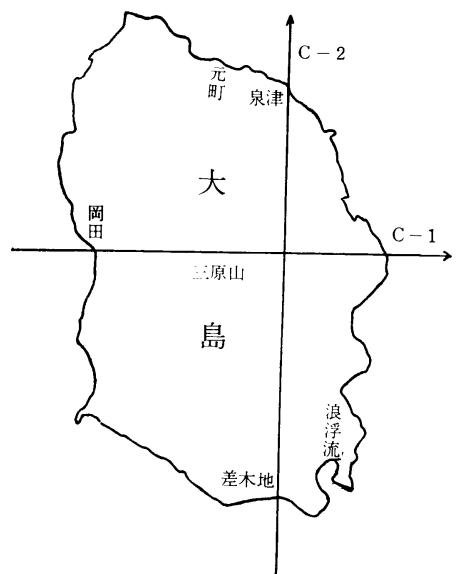

Fig. 5 大島の撮影コース

た。この時の飛行高度は $1350 \mathrm{~m}$ であった。Fig. 6 は この時の結果を示すものであるが, これによると, 海 面上では大体 $23^{\circ} \mathrm{C}$, 森林地带では約 $24.5^{\circ} \mathrm{C}$, 熔岩, 砂漠地带では $26 \sim 27^{\circ} \mathrm{C}$, 極度に温度が高い所は裸地, 畑地, 道路, 民家の所に出現しており, 大体 $27.5^{\circ} \mathrm{C}$ 前後を示していた。この実験に際しては地上における 温度の測定は行なわなかったので地上のそれとは対比 できないが，当日の大島測候所の気像観測資料をまと めて, Table 2 に示しておく。この表の中で, 地温の データーをみると午前 9 時から午後 3 時の間で 27.7 ${ }^{\circ} \mathrm{C} \sim 28.8^{\circ} \mathrm{C}$ の変化をしているが, 撮影時前後でも $28.5^{\circ} \mathrm{C}$ 前後はあるものと推定される。この結果と赤 外線放射温度計による測定結果とを比較すると, 後者 による測定の方が若干低い値を示している。

Table 2 大島の気象資料

（昭和 41 年 8 月 14 日)

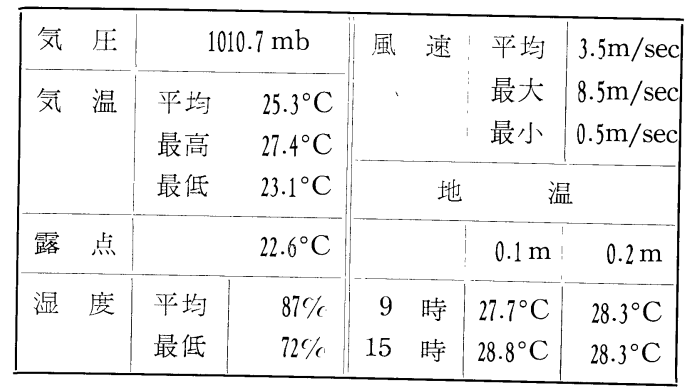

\section{B. 名神高速道路と伊勢湾における実験}

第 2 回目の実験は，1967年 9 月25日に行なわれた。 今回のテストは京都大学防災研究室の奥田博士の指導 により，同研究室との協働によりすすめられた。実験 は名神高速道路, 木曽三川下流流域, 伊勢湾, 名古屋市 街地を選び，地表からの放射をとらえる目的で，早朝 日の出前後から開始し, 赤外線放射温度計による測定 
と同時に地上による測定を行なった。しかし，結果は あまり良いものではなく, 温度の記録は, 温度以外の 振動と共鳴したような記録となり, 解析には苦労させ られた。中でも多少良好な記録を得た所と地上のそれ と比較すると, 名神高速道路面上の場合も木曾三川下 流域の水面上の場合も赤外線放射温度計の方が $2 \sim 3$ ${ }^{\circ} \mathrm{C}$ 低い值を示すようであった。

\section{C. 高野山における実験例}

この実験は, 1967年11月 8 日に, 和歌山県高野山地 域を対象にし, 特に地表被覆状況による表面温度への 影響を知ることを目的として行なった。測定はほぼ午 前11時 30 分から午後零時 30 分までの約 1 時間にわたっ て行ない, 測定方向は東西に1コースとそれに直角に 南北に1コースを選び，それぞれの测定值を得た。

解析方法としては, 温度測定と同調して撮影された 航空写真上に, 飛行基線を含めて地上で約 $100 \mathrm{~m}$ の 幅を持っていると思われる区域について，針葉樹林， 針葉樹低木林(含植栽地), 広葉樹林, 㕕葉樹低木林, 針広混交林, 伐採跡地, その他（野原，畑，裸地）の 7 分類と，それに河川の判読を併せて行なった。その 結果については Table 3 に示すと打りである。
この表の温度読定値をそのまま地表被䨱物独自の温 度とするには, 問題もあり, とりわ地形の温度への 影響はかなり大きいと思われるが，概して言えること は次のと抢りである。

1. 伐採跡地とそれに比較的類似していると考えら れる広葉樹低木村に高温度が見られる。

2.ししい，針葉樹低木林では低温度を示している が，これはサンプルが非常に少ないのでなんとも 言えない。

3. 広葉樹と針葉樹を比較した場合, 㕕葉樹の方が 温度が高い。

4. 林分内に抢ける最高温度と最低温度の較差は, 針葉樹林もしくは, 針広混交林に小さく, 伐採跡 地が最大である。

\section{D. 琵琶湖における実験例}

この実験は，1967年12月12日に行なわれた。今回の 実験为第2 回の実験同梯に京都大学防災研究室の奥田 博士の指導のもとに進められた。測定は，12時01分一 12時29分の間わずか28分間で Fig. 7 に示すように琵 琶湖を一周するコースの観測を終えた。その結果につ いてはFig. 8 に示す。今回の実験でも, 赤外線放射
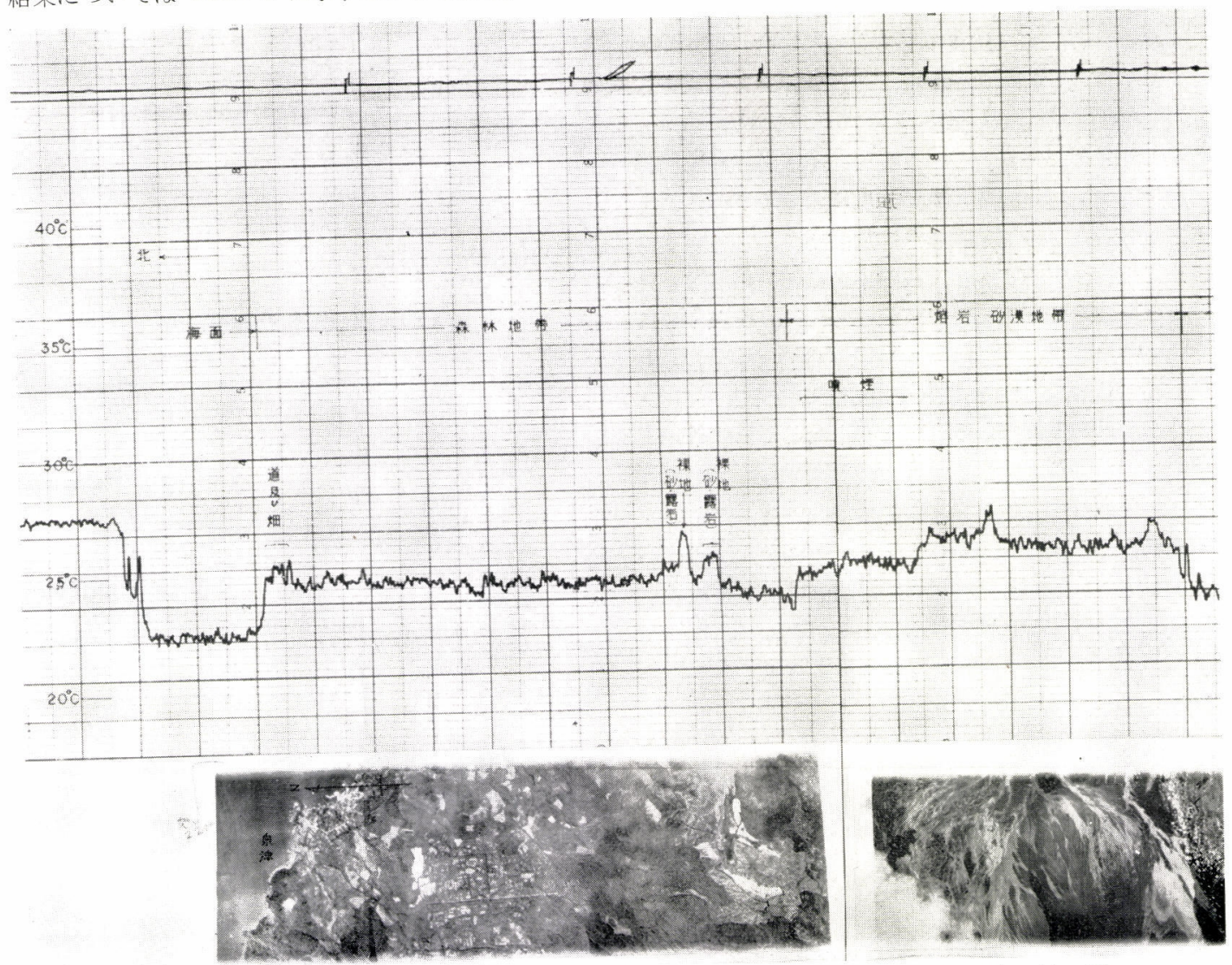

Fig. 6 大島 の 測 定 結 果 
Table 3 高野山における測定結果

\begin{tabular}{|c|c|c|c|c|c|c|c|c|c|c|c|c|c|}
\hline 樹 & & 種 & コース & 最高 & 最低 & 較差 & 平均 & 種 & $=-\pi$ & 最高 & 最低 & 較差 & 平均 \\
\hline 広 & 葉 & 樹 & $\begin{array}{l}\mathrm{C}-1 \\
\mathrm{C}-2 \\
\text { 総平均 }\end{array}$ & $\begin{array}{l}{ }^{\circ} \mathrm{C} \\
14.01 \\
14.55 \\
14.29\end{array}$ & $\begin{array}{l}{ }^{\circ} \mathrm{C} \\
11.49 \\
12.07 \\
11.79\end{array}$ & $\begin{array}{l}{ }^{\circ} \mathrm{C} \\
2.52 \\
2.48 \\
2.50\end{array}$ & $\begin{array}{l}{ }^{\circ} \mathrm{C} \\
12.79 \\
13.31 \\
13.05\end{array}$ & $\begin{array}{c}\text { 針 葉・広葉 } \\
\text { 混 交 林 }\end{array}$ & $\begin{array}{l}\mathrm{C}-1 \\
\mathrm{C}-2 \\
\text { 総平均 }\end{array}$ & $\begin{array}{l}{ }^{\circ} \mathrm{C} \\
12.33 \\
13.80 \\
13.31\end{array}$ & $\begin{array}{l}{ }^{\circ} \mathrm{C} \\
11.17 \\
12.13 \\
11.81\end{array}$ & $\begin{array}{l}{ }^{\circ} \mathrm{C} \\
1.16 \\
1.63 \\
1.50\end{array}$ & $\begin{array}{l}{ }^{\circ} \mathrm{C} \\
11.75 \\
12.97 \\
12.56\end{array}$ \\
\hline 低 & $\begin{array}{l}\text { 葉 } \\
\text { 木 }\end{array}$ & 樹 & $\begin{array}{l}\mathrm{C}-1 \\
\mathrm{C}-2 \\
\text { 総平均 }\end{array}$ & $\begin{array}{l}16.10 \\
15.21 \\
15.75\end{array}$ & $\begin{array}{l}12.14 \\
13.07 \\
12.51\end{array}$ & $\begin{array}{l}3.96 \\
2.14 \\
3.24\end{array}$ & $\begin{array}{l}14.12 \\
14.15 \\
14.13\end{array}$ & 伐採跡地 & $\begin{array}{l}\mathrm{C}-1 \\
\mathrm{C}-2 \\
\text { 総平均 }\end{array}$ & $\begin{array}{l}15.41 \\
16.64 \\
15.87\end{array}$ & $\begin{array}{l}12.05 \\
12.05 \\
12.05\end{array}$ & $\begin{array}{l}3.35 \\
4.59 \\
3.82\end{array}$ & $\begin{array}{l}13.76 \\
14.34 \\
13.98\end{array}$ \\
\hline 針 & 莱 & 樹 & $\begin{array}{l}\mathrm{C}-1 \\
\mathrm{C}-2 \\
\text { 総平均 }\end{array}$ & $\begin{array}{l}13.89 \\
14.05 \\
13.95\end{array}$ & $\begin{array}{l}11.32 \\
12.28 \\
11.68\end{array}$ & $\begin{array}{l}2.57 \\
1.77 \\
2.27\end{array}$ & $\begin{array}{l}12.60 \\
13.17 \\
12.81\end{array}$ & $\begin{array}{l}\text { そ の他 } \\
\left(\begin{array}{l}\text { 野原・田畑 } \\
\text { 裸地 }\end{array}\right)\end{array}$ & $\begin{array}{l}\mathrm{C}-1 \\
\mathrm{C}-2 \\
\text { 総平均 }\end{array}$ & $\begin{array}{l}15.24 \\
15.00 \\
15.21\end{array}$ & $\begin{array}{l}11.75 \\
14.20 \\
12.05\end{array}$ & $\begin{array}{l}3.49 \\
0.80 \\
3.15\end{array}$ & $\begin{array}{l}13.50 \\
14.60 \\
13.64\end{array}$ \\
\hline $\begin{array}{l}\text { 針 } \\
\text { 低 }\end{array}$ & 葉 & 樹 & $\begin{array}{l}\mathrm{C}-1 \\
\mathrm{C}-2 \\
\text { 総平均 }\end{array}$ & $\begin{array}{r}13.20 \\
- \\
13.20\end{array}$ & $\begin{array}{c}9.50 \\
- \\
9.90\end{array}$ & $\begin{array}{c}3.30 \\
\frac{-}{3.30}\end{array}$ & $\begin{array}{r}11.55 \\
- \\
11.55\end{array}$ & 川 & $\begin{array}{l}\mathrm{C}-1 \\
\mathrm{C}-2 \\
\text { 総平均 }\end{array}$ & $\begin{array}{l}- \\
- \\
-\end{array}$ & $\begin{array}{l}- \\
- \\
-\end{array}$ & $\begin{array}{l}- \\
- \\
-\end{array}$ & $\begin{array}{l}12.09 \\
12.54 \\
12.28\end{array}$ \\
\hline
\end{tabular}
C -1 [北 $\rightarrow$ 南]
始 11 時 47 分 終 11 時 53 分
$\mathrm{C}-2$ [東 $\rightarrow$ 西 $]$
始 12 時25分
終 12 時31分

温度計による測定と同時に海上における測温は実施し なかったが, 京都大学理学部付属大津臨湖実験所の測 温資料より推定した水温とを比へると赤外線放射温度 計による方が若干低い值を示している。
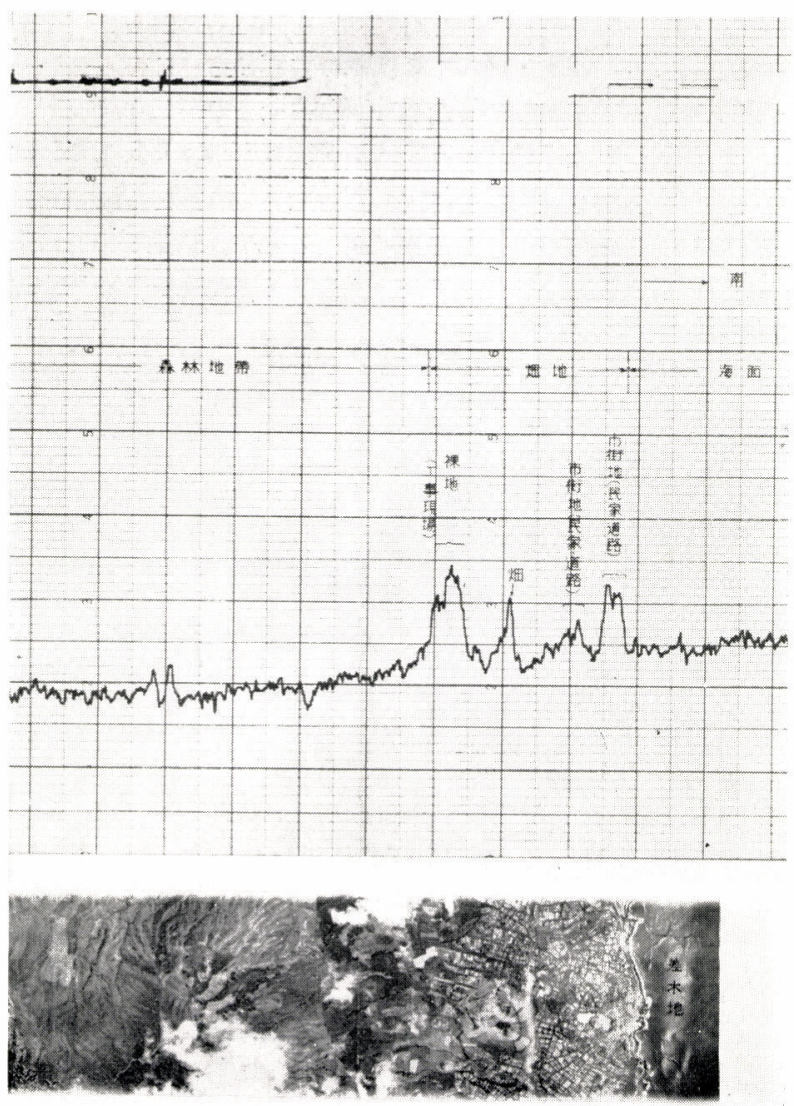

以上，本機の利用を前に行なった実験の一例を紹介 したが，これらの結果はいずれ各々の機関でまとめら れ公にされると思う。この一連の実験の結果を総観す ると, 赤外線放射温度計による観測值は実際の温度よ り低く示されるといら事をのぞけば，大変良好 で 4 項の「本機の特徴」に示した諸点が実証さ れたわけだ。

さて, この温度計による測定值が絶対值より 低くですぎることに関して，筆者等は何度も地 上に拈けるテストを繰返したが，その結果は， わりあい正しい值を示す事から，飛行機に塔載 した時だけあらわれる現象, 寸なわち, 大気中 を通過する赤外線の減衰に起因するものと推論 していた。大気中走通過する赤外線の減衰に関 しては, 前述した選知吸収のほか, 霞, 霧, 雲, 煙霧などによる散乱によるものと温度，気圧 その他によるものがある。このうち吸収に関し ては Fig. 3 に示された結果を斥とに一心無視 して考え, 大気中の散乱によるものと推論した わけだが，実際には，大気中の水蒸気は場所に よっても時間によってもかなり変動するので， 水蒸気による吸収は無視できないか子知れな い。しかし, 今までの実験資料だけでは, これ 以上推論する事は難かしい。

その後, 気象庁予報課の土屋清博士口 の研究 が,この問題に対し, 解決の糸口を与えてくれ た。この結果, 我及が当初意図していた事が本 格的に寒施できるようになったわけである。 


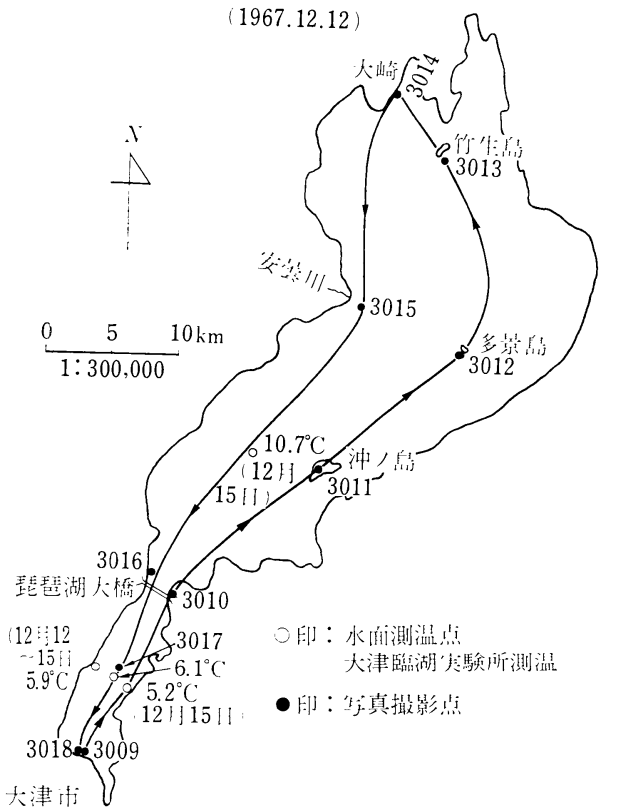

Fig. 7 琵琶湖測温飛行コース

\section{6. むす び}

以上, 赤外線放射温度計の機構と本機を用いての観 測例を紹介してきたが，最後に，本機の今後の利用面 について若干の知見を述べすすびにしたい。

\section{1. 地熱調査}

a. 地熱資源の開発

広大な地域における常温付近の徴弱な温度をあ る広がりを持ってとらえられる事は, 単に地質学,
地球物理学の問題だけでなく温泉探査や地熱発電 のための地熱資源の開発の子祭的な問題解決のた めに大きな効果を果しうる。

b. 火山に打ける熱異常調查

温度測定範囲が $+44^{\circ} \mathrm{C}$ までである事から，活 火山火口内のまたはその周辺の温度については測 定不可能であるが，赤外線映像装置と併用すれば， 赤外線胦像装置の欠点である refarence temperature を把える事ができる。

\section{2. 農業への応用}

a. 土壤温度の测定

農作物の生育と生育期間の土壤の温度の変化に は密接な関係があるが，これらについても最近農 地が大規模化して来ており，なかなか正確に把え がたい。こういう場面でしばしば役立たせうる。 また大規模なパイロットファームの開発に際して の土地条件 (環境) の調査に利用しうる。

b. 啀業用水路, 河川の温度調査 水田に打いて, 特に灌溉用水の水温は水稲の収 獲量の多少に影響を及ぼす。これらについても灌 溉用貯水池等の水温を正確に把えられる事ができ

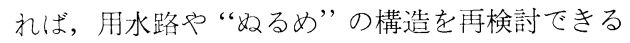
だろう。

\section{3. 陸水・海洋学と漁業への応用}

水面は一様な散乱面とみなす事ができるので， かなり精度の高い水温分布図を描ける。この事は 湖流や湾流の推定も可能ならしめるし, 暖水塊・冷 水塊の分布斗正確に把えられる。結果として，水 温によって生活場所を変える魚類の探知の予察に

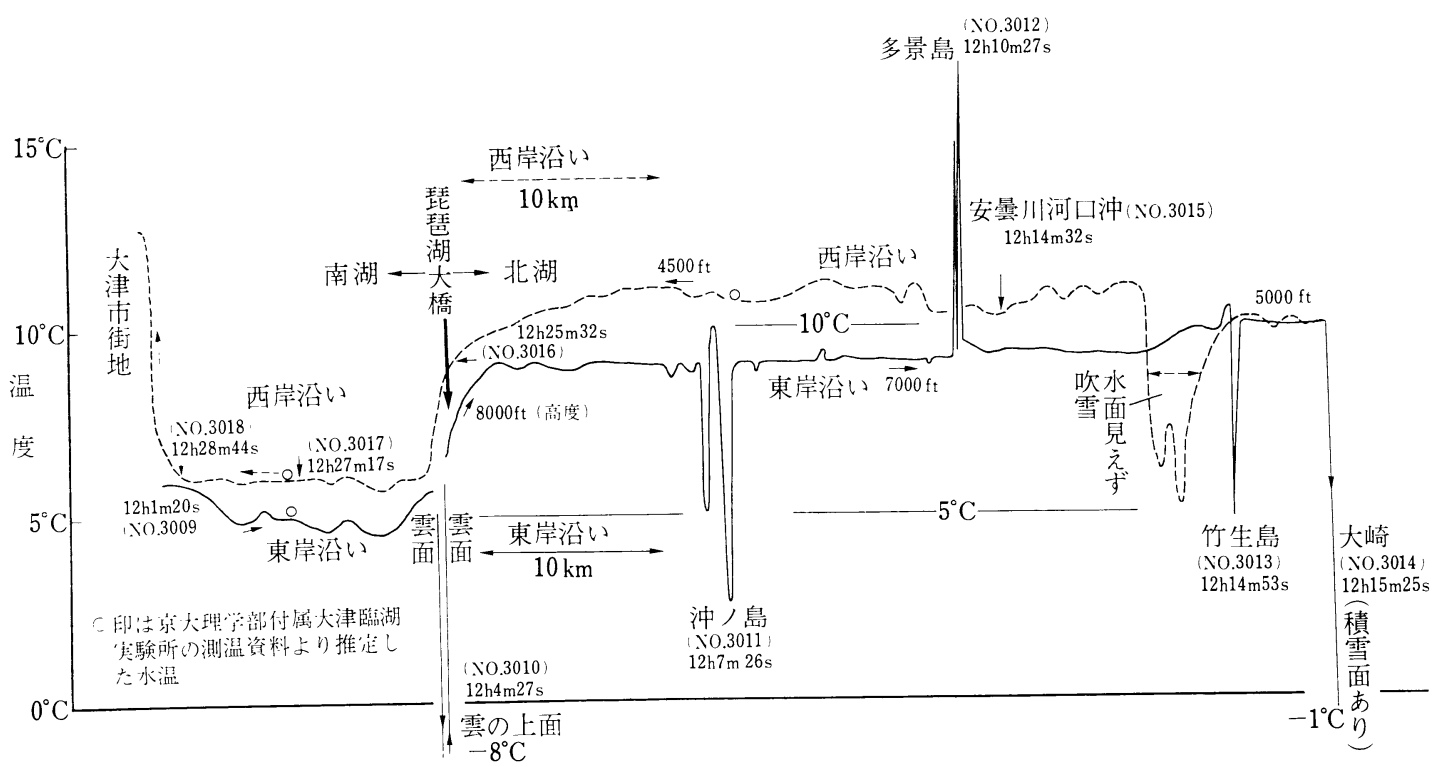

Fig. 8 琵琶湖水面温度測定値（1967. 12. 12） 12 h 2 m 12 h $29 \mathrm{~m}$ 
も貢献しうる。また汀線付近の涌泉の探知や河川 水の河口からの分散状態についても, 海水との温 度差から正確に把えられるであろう。これは海苔 のような沿岸漁業の指針に役立つ。

\section{4. 気象学への応用}

都市気温分布とスモッグの性質, あるいは山腹 斜面温度と雲の発生機構の解明にも多いに役立ち ろるだろう。また森林内の小気候, 特に造林地の 適地適木の決定や保護の資料として利用できるだ ろろし, 冬季, 山腹斜面に形成される冷気湖の発 達等の解明にも，また夏には，南方洋上の海水面 温度と台風の発生機構の解明や地表面における熱 収支の問題解決等, その応用範井は非常に大きい ものと思われる。

\section{5. 災害調査への応用}

a. ナダレと雪面温度の解明

冬季，日本の $80 \%$ は雪に打打われる。同時に 毎年ナダレの災害が発生し，鉄道や道路が大きな 被害を受けるが，これらの機構を解明するにも大 いに役立ちうると思う。

b. 流永と海難防止のために

オホーツク海の流水は, 冬季北方海域において, 漁業に從事する者にとっては危険なものである が，この流水の予報にも利用できるだろう。

c. 熱害調査

最近の工場地帯の拡大は,スモッグとならんで, 工場排水による河川，あるいは港湾の污濁問題を 引き起し大きな公害となってきている。そのうち でも特に, 冷却水の排水による熱污染の把握とそ の機構の解明にも利用できるだろう。

d. 路面温度への影響

日本もいよいよ高速自動車の時代に入ったとい われ，各都市を結ぶ高速道路の建設も急ピッチで 進められているが, 路面温度と交通工学的問題や 早朝, 路面に発生する霧等交通災害の問題に対し ても未だ知られざる面が多い。これらの問題解決 のためにも本機は大いに利用できるものと思う。

以上，筆者等の浅識において，今後の利用面につい て羅列してみたが，この他にもいろいろの分野におい て利用できるのではなかろろか。
このように，連続的に広がりを持つ広範な地域の地 表面温度を短時間に測定できるという事は, 単に気象 学上, 海洋学上, あるいは地質学や地球物理学上画期 的な方法であるばかりか, 熱污染やナダレ, スモッグ 等の災害調査のためにも大いに活用できよう。更に, 新産都市の建設や，パイロットファームの開発等の建 設に伴う環境調査のための基礎資料にもこの方法を駆 使し, 研究調査される事が望まれる。同時に本機の観 測結果から絶対温度を決定する方法についても更に多 くの実験が必要だろろし，測定のための航法などに関 する問題についても今後取り組まねばならない。これ らに向かって一歩一歩基礎資料の蓄積をはかる事も必 要である。

謝辞 本稿をまとめるにあたって，装置の改良に当 られたアジア航測 K.K 器材整備室の小山氏に, また 撮影ならびに航法の問題に対して研究された同社運航 部の滝沢，中村，一渡の各氏に謝意を表する。

また，温度の補正や野外実験において種々御指導下 さった京都大学防災研究室の奥田博士に謝意を表す る。

\section{赤外線放射温度計に関する文献}

1）松野久也: 遠隔探知方式について 1-1, 論評 写真測量 Vol. 6 No. 2, pp. 29 33, 1967.

2) 松野久也, 長谷紘和: 熱線写真について, 写真 測量 Vol. 5 No. 2, pp. 22 28, 1966.

3) 土屋 清: 空から地表温度をはかる, 科学朝日 1968，6月号 pp. 89〜94.

4) Barnes. R.C: Model PRT-4 Portable Radiation Thermometer Barnes Engineering Cohtd. Pefense and space division, Stamford Conneticut. 1966.

5）小山幸雄, 黒岩五郎: 赤外線放射温度計及びそ の記録装置などの取扱い説明書, アジア航測 $\mathrm{K}$ K技術文献経，pp. 1 2, 1967 .

6) Carl F. Konoshi : Water and Cloud temperatures measured from V-2 Aircraft, Bulletin American Meteorological Society Vol. 45 No. 9, pp. 581 586, Sep. 1964.

7) Donald H. Lenschon, John A. Dutton: Surface Temperature Variation Measured from on Airplane over Several Surface Types Journal of Applied Meteorology Vol. 3, pp. 65 69, Feb. 1964 . 